\title{
A Study of the Neurolinguistic Features of Programming Unhealthy Personality Mindset: A Case Study of the Language of Affection in the Qur'an
}

\author{
Hussain Hamid Hussain $\mathrm{Ali}^{1}$ \\ ${ }^{1}$ Lecturer of Linguistics and Translation, Department of English, Faculty of Languages and Translation, \\ Al-Azhar University, Egypt \\ Correspondence: Hussain Hamid Hussain Ali, Lecturer of Linguistics and Translation, Department of English, \\ Faculty of Languages and Translation, Al-Azhar University, Egypt. E-mail: hussainghazzali@azhar.edu.eg
}

Received: December 30, 2019

Accepted: January 30, 2020

Online Published: December 16, 2020

doi:10.5539/ijel.v11n1p179

URL: https://doi.org/10.5539/ijel.v11n1p179

\begin{abstract}
For a start, the present study tackles the language of affection in the Qur'an and its role in managing unhealthy personality. Primarily, it provides a full-scale model for programming unhealthy mindsets. The model uses linguistic and neurological tools in the process of analysis. Affectional language is a case in point that shows how language, emotions, and cognition interact to reflect each other. The study highlights the effective role of affectional language in shaping minds. In the same vein, a typical example for the neurological programming process is the Qur'anic representation of the attitudes of some believers at the time of the Prophet Muhammad (PBUH) after a specific battle. This representation reports the initial reaction of the believers which is emotionally shaped. Also, it helps in making proper reactions which are shaped according to the normal pathways of thinking. The process of shaping cognition is carried out according to specific neurological strategies that include the proper process of sensation, retrieval of the previous experience, neuroplasticity, and acceptance. Also, these strategies include self-compassion and compassion for others. Adding to its motivational role in the promotion of forgiveness, it plays the same motivational role for doing justice. Accordingly, the study concludes that the discourse of affection plays an effective role in shutting the door on any potential sign of the hurt-perceived and the righteous indignation reactions. Furthermore, it combats radicalism and extremism in a way that ends all forms of violence.
\end{abstract}

Keywords: affection, cognition, discourse, emotions, neurolinguistics, programming

\section{Introduction}

The present study provides an analysis of the language of affection in the Qur'an. It focuses on the motivational role of the language of affection in transforming negative mindsets into positive ones. In addition, it provides new and different approaches for analyzing the Qur'anic text. These approaches include neurological and linguistic tools in the process of analysis. It aims at having a true understanding and an authentic interpretation of the Qur'an. Besides, addressing the motivational role of the language of affection helps in managing any potential sign of a negative mindset. In this regard, it deals with the development of both the hurt-perceived and the righteous indignation reactions. Furthermore, it tackles the strategies of transforming these negative frames into positive and constructive ones. In addition, the paper highlights the linguistic forms of causality that link these negative frames together. The language of affection plays an effective role in ending any sign of rumination that can develop into aggressive behaviors. In conclusion, the study earns itself to whoever is interested in ending all forms of violence all over the world by dissipating the true values of religions.

\section{Objectives of the Study}

Tackling the linguistic phenomenon of affection in the Qur'an aims at addressing the following points:

a. Providing new tools for analyzing the Qur'an with a view to getting an authentic interpretation of the psychological and neurological aspects of the Qur'anic text.

b. Identifying the neurolinguistic features of the discourse of affection that help in dissipating the true values of Islam. 
c. Identifying the relationship between the motivational role of affectional language, the inhibition of the destructive values and the promotion of forgiveness.

d. Highlighting the role of affectional language in combating radicalism.

\section{Methodology}

The study uses an eclectic approach that consists of linguistics, psychology, and neurology. These three elements affect each other. Cognitive structures shape emotional reactions which in turn take specific linguistic forms in the process of representation. The study makes a link between the two models of McCullough and Greenberg in the process of analysis. Under psychology, McCullough (2000) provides a psychological depiction of the characteristics of unhealthy personality. It consists of the hurt-perceived and the righteous indignation mindsets. The hurt-perceived reaction includes complaint, whining, and claiming victimhood. The righteous indignation mindset includes revengeful reaction and deservingness. Under neurology, Greenberg (2016) provides the strategies of the neurological process of programming the unconstructive mindsets above. The transformation of these mindsets from negative into positive takes place through specific strategies such as neuroplasticity, acceptance, understanding, self-compassion and compassion for others. The process of analysis starts with analysing the linguistic features of the values of the hurt-perceived and the righteous indignation mindsets making use of McCullough's model. Then, there is an analysis of the linguistic features of the neurological process using the strategies of Greenberg. The inhibition of the unconstructive mindset and the promotion of the constructive mindset are motivated by the divine language of affection. To achieve the objectives of the study, all situational aspects are considered to get an authentic interpretation of the Qur'anic text.

\subsection{Data of the Study}

The primary data is obtained from the All-Glorious Qur'an. The study tackles the affectional form of

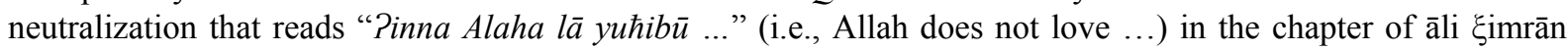
(3:140). It focuses on its relationship with the preceding and the following verses in programming mindsets. So, the process of analysis covers the verses below highlighting the psychological and cognitive features of the linguistic units. Here are the verses:

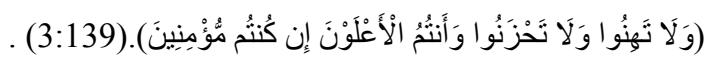

So do not become weak (against your enemy), nor be $\underline{\underline{s a d}}$, and you will be superior (in victory) if you are indeed (true) believers. (āli ̌̌imrān 3:139 AI-Hilalī, M. \& Khān, M.).

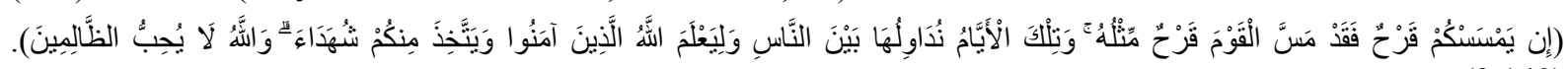

If a wound (and killing) has touched you, be sure a similar wound (and killing) has touched the others. And so are the days (good and not so good), We give to men by turns, that Allah may test those who believe, and that He may take martyrs from among you. And Allah likes not the zālimīna (polytheists and wrong doers). (äli 乡̧imrān $3: 140)$.

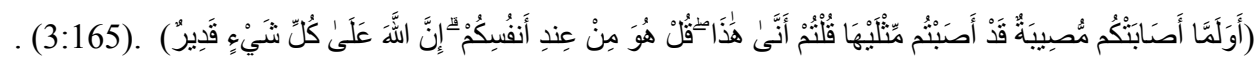

(What is the matter with you?) When a single disaster smites you, although you smote (your enemies) with one twice as great, you say: "From where does this come to us?", (Say to them) "It is from yourselves because of your evil deeds)". And Allah has power over all things. (āli 乡̧imrān 3:165).

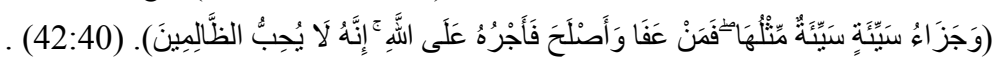

The recompense for an evil is an evil like thereof; but whoever forgives and makes reconciliation, his reward is with Allah. Verily, He likes not the zālimīna (oppressors, polytheists, and wrong doers). (ash-Shüra 42:40).

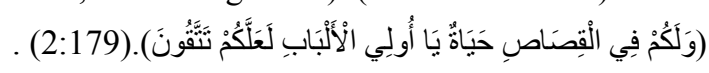

And there is (a saving of) life for you in Al-Qişāş (the Law of Equality in punishment), O men of understanding, that you may become Al-Muttaqun (the pious - See V.2:2). (al-Baqarah 2: 178).

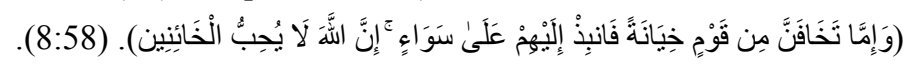

If you (O Muhammad) fear treachery from any people throw back (their covenant) to them (so as to be) on equal terms (that there will be no more covenant between you and them). Certainly, Allah likes not the treacherous. ( 8 : 58). (al-Anfäl 8:58).

\section{A Hurt-Perceived Mindset: Linguistic Forms}

In the lines below, the process of analysis addresses the forms of the hurt-perceived frame. It is one of the modes 
of reaction to stressful situations that forms the nucleus of the phase of action. Sensing a threat, the offended may respond emotionally. This reaction falls under the frozen mode which precedes the phases of action. Greenberg (2016, pp. 3-4) states that "in face of dangers, the offended can adopt one of three modes: fighting, fleeing, or freezing". Instead of taking an action of fighting or fleeing, the offended may resort to freezing his reaction. According to McCullough (2000, p. 44), the hurt-perceived mindset is characterized by the feelings of worry, whining, fear, and claiming victimhood. To give an accurate description of the linguistic forms of the hurt-perceived mindset, a case in point is the state of the believers at the battle of Uhud. After the battle, they expressed their anger, astonishment, and sadness of what happened. So, the Qur'anic verses depict their initial inappropriate reactions. Their rhetorical question "Panna hätha" (i.e., how this happens to us?!) in the verse (3:165) below is an encapsulated form of all the components of the hurt-perceived values.

\subsection{Contextualization of the Case Under Analysis}

The Qur'an makes an accurate representation of the case of the battle of Uhud. The process of representation is

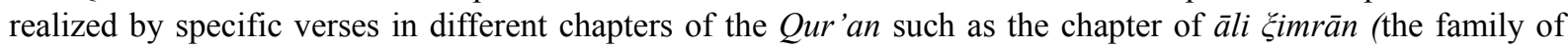
Imrān) and an-Nahl (the Bees). These verses depict every aspect of the battle in which the believers suffered after being victorious. The Prophet (PBUH) ordered the archers to stay at their places on the mountain of Uhud whatever the case may be. They did not fully comply with the instructions of the Prophet Muћammad (PBUH). The archers left their places when they saw that Muslims won at the start of the battle. Making use of this gap, Khaled bin al-Waleed attacked Muslims at the battlefield. This attack turned the table on Muslims leading to the martyrdom of about seventy of the Prophet's companions. One of the martyrs was Hamza bin $\xi a b d$ al-Mutalib, the Prophet's close uncle. Some of the believers showed unacceptable behaviours that are at variance with the established morals of Islam. To correct such psychological behaviours, specific Qur'anic verses were revealed. One of the verses reads:

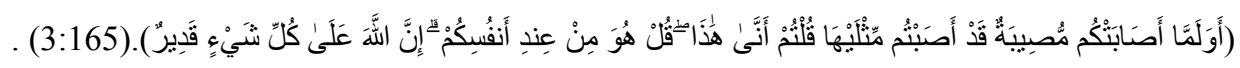

What is the matter with you? When a single disaster smites you, although you smote (your enemies) with one twice as great, you say: "From where does this come to us?", (Say to them) "It is from yourselves because of your evil deeds)". And Allah has power over all things. (äli 乡̧imrān 3:165).

The verse identifies the psychological nature of the attitude of the believers and handles it neurologically. It sets an example of the normal response to hurtful conditions considering the Qur'anic instructions. Despite the troubles and the suffering which they faced at the hands of the unbelievers, the Prophet (PBUH) and his companions adopted a peaceful and friendly approach towards the unbelievers after the revelation of this verse and other verses. They set an example of the normal pathways of thinking in dealing with stressful situations.

\subsection{Rumination: A Mode of Activation}

The first form of the hurt-perceived reaction which the verses below diagnoses is rumination. It has a metaphorical origin of chewing the cud that stands for turning over and over something in the mind. Greenberg (p. 149) defines it as the process of persistent and repetitive worry in which the ruminator revisits the same information repeatedly without finding any new answers. Rumination thoughts go from a positive mindset into a negative mindset. It starts by raising questions that aims at adjusting the situation. Then, these questions create negative emotions that lead to abnormal ways of thinking. Potter-Efron (2011, p. 1) gives an exact description of the interaction between cognition and emotions stating that they are two sides of the same coin in a way that each one affects the other. It is a vicious circle that the brain develops angry actions which in turn influence every neuron in the brain. These mindsets make the ruminator feel that everything is going normal. Greenberg (p. 150) stresses that rumination is the result of a vicious circle of the improper interaction between the emotional system and the cognitive system as demonstrated below.

\subsubsection{Hurt-Perceived Values}

The features of rumination are whining, complaining, and claiming innocent victimhood which are realized by the rhetorical question form. The adoption of any of these forms develops a destructive mental frame. Turning over and over these feelings in the mind has its own negative impact. It is realized by the believers' saying: "Panna hätha" (i.e., how this happens to us, Muslims). Their rhetorical question flags an attitudinal tone of whining and claiming innocent victimhood. Löbner (2002, p. 32) states that "every utterance serves, consciously or not, the expression of personal feelings, evaluations and attitudes".

So, the believers' saying, "how this happens to us?!", is a rhetorical question that has the function of flagging their anger and claiming innocent victimhood. Also, it registers their complaint and astonishment being exposed to a hurtful condition. To correct their stance, their rhetorical question is embedded in another rhetorical question. 
The main rhetorical question has the function of denunciating their reactions. It aims at transforming their mindset from getting into a negative mindset into a constructive one. The process of transformation is carried out according to the normal pathway of thinking. It is mainly motivated by the divine language of affection which encourages the believers to adopt such mental positive frames in face of stressful situation.

\subsubsection{Ineria}

Inertia is a main feature of rumination in which the values still the same. Neurologically, it is the result of the lack of a planned reaction. Inertia is a tendency to remain unchanged, so the ruminator still has the same negative mindset. It refers to the degree to which emotional states are resistant to change. The Qur'an strongly rebukes

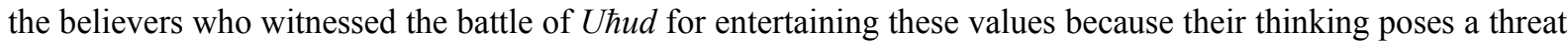
for both individuals and society. Inertia revolves around the feelings of sadness and despair which are a result of rumination. Before handling rumination, the Qur'an initiates the process of neurological programming by inhibiting both despair and sadness in a verse that reads:

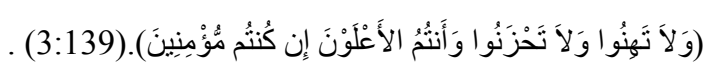

So do not become weak (against your enemy), nor be sad, and you will be superior (in victory) if you are indeed (true) believers. (āli ̌̌imrān 3:139).

This verse depicts two features of inertia: despair and sadness. The first process 'wahana' (i.e., become weak) indicates a physical weakness. Metaphorically, it stands for 'the lack of will'. The question raised here is 'why does the verse place emphasis on these two processes?'. To answer this question, it is important to quote Potter-Efron (2012, p. 85) as saying there are two types of emotions: primary emotions such as fear and sadness and social emotions such as embarrassment. The first type of primary emotions is realized by the process "ћazana" (i.e., be sad). The second type of social emotions is realized by "wahana". Therefore, these two processes represent two types of emotions which are undesirable and prohibited. So, the verse combats any negative social and personal feelings which show why the verse places emphasis on them. The first process 'wahana' stands for inanition and lassitude and the second is sadness which is undesirable when it relates to weakness. Moreover, holding such things in the mind may lead to depression. These two emotional processes can open the door for entertaining enmity towards self and others. On one hand, it is enmity towards self because it causes psychological diseases such as depression. On the other hand, it is enmity towards others because it brings into confrontation. The Qur'an goes on to provide a neuro-linguistic programming of any mindset of that kind. Accordingly, it is undesirable because the essence of the message of the Qur'an is unity and co-existence between humans.

\section{The Neurolinguistic Features of Programming Negative Mindsets}

To inhibit the development of the values mentioned above, the verses under analysis provides a neurolinguistic programming of such mental frames. The process starts with an accurate depiction of the potential hurt-perceived mindset of some believers registering their initial emotional reaction. Then, it handles such mentality making use of the strategies of the retrieval of previous experience, neuroplasticity, acceptance, optimism, and understanding. These strategies are motivated by the neutral form of affection which plays the same role in the inhibition of the righteous indignation values.

\subsection{Instant Emotional Reaction}

In the preceding sections, we tackle the first process of cognition, the emotional reaction and how the verse handles them. The use of the rhetorical question in the verse depicts the cognitive and emotional reactions of the believers. To get a thorough analysis of the verse, it is useful to deconstruct the verse into clauses using numbers as follows:

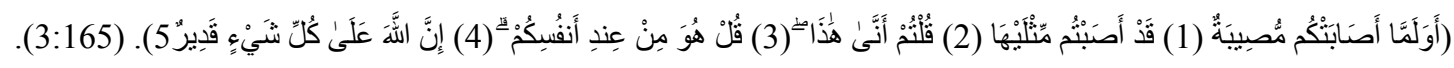

What is the matter with you?) When a single disaster smites you, (1) although you smote (your enemies) with one twice as great, (2) you say: "From where does this come to us?", (3) (Say to them) "It is from yourselves because of your evil deeds)". And Allah has power over all things (5). (āli گ̌imrān 3:165).

To make it easy in the process of analysis, we refer to the clauses in the verse above using the number within brackets. The verse consists of a dependent clause (1), an adjectival clause (2), a verbal clause which is the main clause (3). Each clause represents a specific psychological value and a neurological function. In this section, the process of analysis focuses on the dependent clause number (1) and the verbal clause number (3). The latter consists of the sayer, the process, and the verbiage. The dependent clause represents the believers' experience of suffering and what happens to them. Therefore, this clause depicts the believers' reception of the defeat at the 
end of battle of Uhud. The use of the conjunction of the adverbial clause of time "lamma" (i.e., once) indicates instancy and immediacy that they respond emotionally without taking time to deliberate. Therefore, the use of the conjunction flags an overtone of rejecting such an instant reaction. The verse lays the foundations for the strategy of 'being in the moment' instead of the strategy of "doing". It would be better to freeze one's reaction without any attempt to deliver judgments as Greenberg (p. 66) asserts. As for the verbal process, it represents their emotional reaction that the believers reacted emotionally without deliberateness and meditation. Thus, the attribution of the verbiage to the sayer (i.e., the believers in this case) has the function of criticizing their immediate reaction that once they faced difficult times, they expressed their astonishment, complaining and claiming victimhood. It is undesirable to produce an immediate response of this kind because it lacks deliberation that makes it more effective. Thus, the two clauses (1 and 3) in the verse reflect the believers' ineffective way of thinking. The use of the adjectival clause (2) after the dependent clause (1) has the function of correcting the abnormal pathway of thinking. It conveys that once they face a trouble, they should retrieve their successful experience in the past.

So, the verse uses the adjectival clause "qad Paşabitum mithlayha" to draw their attention to the normal and the true pathway of thinking. It reminds them of their successful experience of winning the battle of Badr. Similarly, it refers to their improper process of thinking and their stance of claiming victimhood which are in direct contradiction with what really happens. Commenting on the believers' behaviour at this battle, ash-Shałrāwy (1991, p. 1861) states that the believers expressed their astonishment of what happened despite their disobedience of the commands of the Prophet Muћammad (PBUH). So, the believers' behaviours are strongly criticised. The verse aims at nipping in the bud any attempt for entertaining any value of the destructive frame. So, their behaviours are condemned and corrected by the neuro-programming processes below.

\subsection{Claiming Perfectionism}

In the same vein, the verse condemns the attitude of claiming perfectionism. The believers' saying "Panna hätha" (how this happens to us?!) reflects their attitudinal positioning. Their rhetorical question conveys something like 'how did we, Muslims, suffer?!'. It is that attitude that makes them astonish and express anger. The verse criticises them for falling in the trap of perfectionism. It tells them that they did not meet the requirements of perfection; therefore, they did not have the right to claim it. In his commentary on the believers' stance at this situation, ash-Shaל̧rāwy (1991, p. 1781) states that reaching the state of perfection, a believer should be an epitome of the true faith having all the true characteristics of the true believers. (Translation is Mine).

\subsection{Neuroplasticity}

Greenberg (2016, p. 4) states that "You can grow new brain neurons; create new, positive, and productive brain pathways; and enlarge the parts of your brain that help you think clearly so that you view life stressors as manageable challenges rather than insurmountable threats". Being criticized for their emotional reaction, the verse corrects the behaviours of the believers. This is done by drawing their attention to one of the most important processes of the right-thinking pathways. It is the restoration of their previous experience which is realized by the adjectival clause (3) in the verse above "qad Paşabtum mithlayha" (you smote your enemies with one twice as great). It tells the believers that once you face a difficult time, you should have a neuroplastic mindset restoring your previous experience of success. Therefore, it instructs them of the inherent pathways of thinking instead of whining and complaining. The believers should switch from a rigid mindset into a more flexible mindset. Up to the present moment, we analyse three clauses of which two clauses identify the case and condemn it while the third clause prescribes the treatment. It denunciates the values of the hurt-perceived mindset aiming at creating a flexible one. Therefore, it is important to link the present situation with the previous experience to overcome difficult times.

\subsection{Acceptance}

In addition to drawing attention to the proper processes of sensation and restoration of the previous experience, there is the process of acceptance that matches with the order of the clauses in the verse. It is a means of overcoming the emotional reaction and a result of linking the present situation with the previous experience. It is an order that goes in line with the normal pathway of thinking. Greenberg (p. 86) states that "Whatever the present moment contains, accept it as if you had chosen it. Always work with it, not against it. Make it your friend and ally, not your enemy". Therefore, the verse refers to the importance of overcoming the first shock. It is realized by the verbal clause number (4) in the verse: "qul huwa min $\xi$ indi anfusikum" (i.e., this misfortune is self-inflicted). The Prophet (PBUH) refers to this process when he says, "Indeed, it is patience at the first shock of a misfortune that counts" (al-Bukhāri, 2002, p. 1302). Therefore, the verse tells them to admit responsibility for their suffering. They should not be trapped into the cage of the rigid mindset. 


\subsection{Optimism: Always Seeing the Glass as Half Full}

In line with the normal pathways of thinking, optimism is the fourth phase which is reflected by the fifth clause that reads: "Pinna PAllah گ̧ala kulli shayPin qadīr" (i.e., Indeed, Allah Has power over all things). After directing the believers to the proper way of thinking, the verse opens the door for optimism. It draws their attention that they should look at the glass as half full as a means of combating the forms of inertia in the preceding sections. So, if inertia develops depression, optimism makes the offended healthier and wealthier according to Warrell, M. (Sep 19, 2012, para 3). Instead of showing astonishment and complaining, the believers should work properly. If they follow the normal pathways of thinking, it is then that God takes their side. Moreover, adopting this normal process of thinking decreases the risk of developing psychiatric diseases such as depression on which the verse places emphasis to avoid.

\subsection{Understanding}

The inhibition of despair and sadness is a constructive means that paves the way for understanding. If rumination leads to a reduction of social support, the inhibition of these two values builds rapport with other people. Developing understanding is a key objective behind the inhibition of despair and sadness. Chronic ruminators appear to behave in ways that are counterproductive to their relationships with family, friends, and even strangers. Nolen-Hoeksema et al. (2008, p. 403) state that rumination leads to negative thinking because a depressed person tends to retrieve more negative memories from their recent past and recall negative events (Note 1). Turning these memories over and over results in depression. Also, Koval et al. (2012, p. 1412) argue that "rumination is a result of the repetitive cognitions that focus on the causes and consequences of depressive symptoms". Both rumination and emotional inertia independently contribute to depressive symptoms which are main characteristic of radicals nowadays.

\subsection{Neutralization}

All the cases of the neurolinguistic programming in the preceding sections [5.1-5.6] are motivated by affectional language of the Divinity. To inhibit any potential destructive frame, the discourse of affection mediates between negative emotions and the neurolinguistic management of these negative emotions aiming at changing negative mindsets into positive ones. The verse reads:

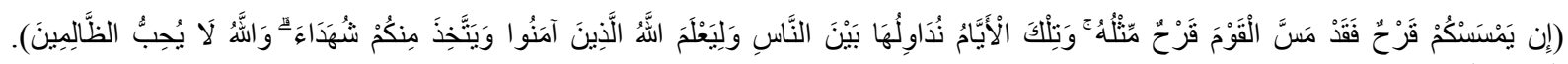

If a wound (and killing) has touched you, be sure a similar wound (and killing) has touched the others. And so are the days (good and not so good), We give to men by turns, that Allah may test those who believe, and that He

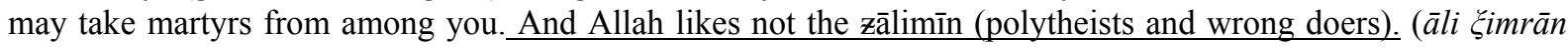
$3: 140)$.

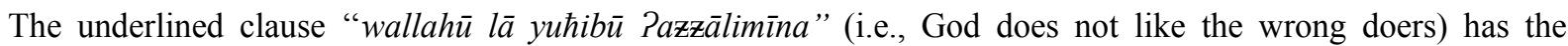
function of neutralizing emotional responses of the believers. It is a concluding sentence which plays a pivotal role in the process of managing emotions and shaping cognition. It is the process around which the preceding and the following verses revolve. Its function is a warning for the believers to keep away from any of the components of the ruinous mindset. Therefore, when a believer faces a stressful situation, he should act in the right way cognitively and emotionally. It is healed by the state of neutralization which is realized by the form "la $y u \hbar i b . . . "$ (i.e., God does not love...). Therefore, the language of affection is used for controlling both the cognitive and psychological cases above. It is unfair to respond inappropriately because it is harmful for self and for others. Once the normal pathways of thinking are secured, ruinous values have no place in the believer's life. This motivational language plays a major role in inhibiting negative energies of which are the two cases given in the righteous indignation below.

\section{Righteous Indignation Mindset}

Righteous indignation frame finds its way when there is a failure to promote a positive mindset. It is the phase of action which the divine language of affection wants to control in the first place. Controlling cognitive and emotional processes aims at controlling behaviour in essence. Behaviour is the phase of action which comes under the frame of the righteous indignation. Perception comes first before emotion and action comes final. The main features of the righteous indignation frame are deservingness, revenge, and aggression. These features are closely intertwined. In the lines below, there is a discussion of how this mental frame is developed cognitively and psychologically.

In a nutshell, the development of the righteous indignation frame is an outcome of the lack of neuronal regeneration. Such a lack makes it difficult to manage the hurt-perceived psychological disorders. Due to such an 
inability to generate new neurons, the brain does not work properly; henceforward, it will not respond effectively. The states of rumination and inertia are the primary cause for the lack of neuronal regeneration. These two processes create a disinclination to change in a way that leaves no place for experiencing new emotions; therefore, they lead to deservingness, revenge, and aggression. Accordingly, a main feature of these mindsets is causality that rumination leads to inertia which in turn results in revenge. This reflects that the righteous indignation mindset is neurologically motivated. The lines below reveal how the Qur'an manages the indignation frame in a different way than some psychological studies have done.

\subsection{Revenge and Its Moral Status}

The desire for revenge is a main feature of the frame of the righteous indignation. Failing the inhibition of the hurt-perceived values, the offended develops a desire for revenge. In a questionnaire prepared by Debate.org, "Can revenge be justified?" (n.d.) found that $56 \%$ for revenge and $44 \%$ against revenge. Some psychologists hold that revenge is an equivalent for punishment. This view is buttressed by some evolutionary theorists as Knutson (2004, p. 1246) who argue that the strategy of an eye-for-an-eye is effective in a way that prevents future damage to one's self and kin. Their justification assumes that revenge makes the offended feel that justice is re-established. On the other hand, it makes the offender and the offended feel what he deserves according to Gollwitzer and Denzler (2009, p. 14). They state that once the offended suffers the same amount of harm and loss, the goal is fulfilled. So, revenge seeks emotional balance since it makes the offended feel that justice is re-established, and everyone got what he or she deserved. Contrary to this view, there are other studies that condemn revenge. Hughes (2015), as cited in Scheiter (2016, p. 314) states that forgiveness is preferable to revenge, which he claims does not appear to have any real benefits. He points out that acts of revenge often lead to cycles of violence and those who seek revenge are typically left feeling unsatisfied or empty

However, in the process of handling such psychological negative emotions, the Qur'an does not hold revenge or any of the values of the indignation frame as righteous values. To manage these destructive mindsets, the Qur'an lays the foundations for a legalized culture. So, it makes a close correlation between the strategies of an-eye-for-an-eye and a-soul-for-a-soul and law. It means that these strategies must be carried out under the umbrella of law. To establish justice, the Qur'an sets out strict rules for getting the offender accountable for his offenses. Therefore, there are divine rules and judicial systems that carry out law strictly. Abiding by law is a guarantee for justice and fairness. If it is left to revengeful soul, there will be a vicious circle of violence, retaliation, and life of the jungle. The All-Glorious Qur'an tackles revenge from a different perspective shutting the door on revenge more than 1440 years ago. To overcome such a destructive value, it shapes the believers' cognitive and emotional mindset properly. This is achieved by making the believers feel a pleasure at offering forgiveness. Even it makes a step forward encouraging them to forgive in the fairest way. Therefore, the Qur'an condemns all forms of indignation because they lead to cycles of violence.

\subsection{Self-Compassion and Compassion for Others}

The first choice for the believers is to have compassion for themselves and for others in their reaction to an offense. It goes without saying that the language of affection helps in shaping the behaviour of the believers in a constructive way. Their cognitive and psychological setup is a positive mindset. Moreover, it encourages self-compassion and compassion for others at the first place. This is realized by the conditional sentence in the first part of the verse that reads: "wa laPin şabartum lahwua khayrun liş-şābrīn" (i.e., and if you endure patiently, indeed, it is better for the patient). Primarily, it encourages the believers to freeze their stance by being patient. A frozen mode takes two forms: a. the mode of inertia which is denounced in the preceding sections, and b. the mode of patience which is desirable as in this case. It is one of the ways of overcoming revenge. Having compassion for others is the first brick for bringing in peace and promoting harmony. This is buttressed by another verse that promotes hope. It reads:

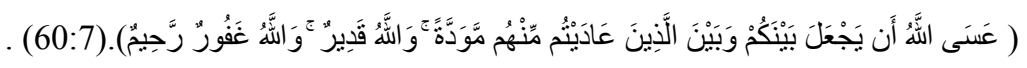

Perhaps Allah will make friendship between you and those whom you hold as enemies. And Allah has power (over all things), and Allah is Oft-Forgiving, Most Merciful. (al-Mumtaћanah 60: 7).

The verse promotes hope in a way that has the function of constructing positive relationship with others. This is achieved by recommending forgiveness which is a result of being compassionate for others.

\subsection{A Legalized Culture Frame}

If the Qur'an encourages the offended to have compassion for themselves and for others, it sets the rules for bringing in justice and fairness for all. Therefore, compassion is a means for eliciting forgiveness; otherwise, all parties should resort to litigation. The Qur'an denounces all forms of vengeance and encourages the believers to 
forgive for the sake of harmony in communities. So, the case of offense or hurtful conditions are managed neurologically and psychologically well. In completion to the strategies of the battle of Uhud for facing stressful situations, there are three other strategies: the self-compassion, the compassion for others and legality as in the verse that reads:

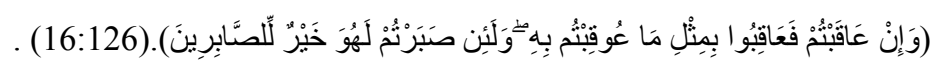

And if you punish (your enemy, $\mathrm{O}$ you believers in the Oneness of Allah), then punish them with the like of that with which you were afflicted. But if you endure patiently, verily, it is better for As-Säbirün (the patient). (an-Nahl 16:126).

\subsubsection{Contextualization of the Verse}

It may be asked 'what is the relation between this verse and the language of affection?' The answer for that question is as follows: the verse is one of the verses that were revealed after the battle of Uhud. Therefore, it falls under the general rule of neutralization of emotions with a view to combating any sign of unfairness. In addition to the textual analysis below, there is the contextual analysis of the verse which refers to the social context in which the verse was revealed. It happened that a great number of the companions of the Prophet (PBUH) were martyred by the unbelievers. Even the Prophet's uncle Hamza was martyred at the hands of the unbelievers of Mecca according to Ibn Kathīr (1999, pp. 134-135). For this reason, the verse handles the desire for retribution by the companions of the Prophet after the battle of Uhud. So, it frames the case legally instructing them that if it happens that they punish them, let them be punished in a similar way that you suffered no more no less. Interestingly, the verse uses the verbal process " $\xi \bar{a} q a b a$ " (i.e., punish) three times to stress the principle of fairness that their reaction should come under a legal framework. Then, it makes it difficult to achieve a return because the idea of the same amount of punishment is impossible to achieve. The lexical repetition of " $\xi \bar{a} q a b a$ " has the rhetorical function of nipping the desire for revenge in the bud. To reach an accurate analysis, it is important to do a textual analysis of the verse as in the table below.

Table 1. A Linguistic analysis of the verse (16:126).

\begin{tabular}{|c|c|}
\hline Forms & Grammatical and semantic Analysis \\
\hline Pin & $\begin{array}{l}\text { conditional form that conveys the meaning of downtoning. It decreases the possibility of imposing } \\
\text { unishment hoping for forgiveness. }\end{array}$ \\
\hline$\xi \bar{a} q a b t u m$ & $\begin{array}{l}\text { An unreal past form that does not refer to something that happened in the past. Therefore, the if-clause is } \\
\text { used for downtoning. }\end{array}$ \\
\hline$\xi \bar{a} q i b u$ & $\begin{array}{l}\text { It is a conditional main clause that indicates similar punishment. The act of stipulating the degree of } \\
\text { 'sameness' makes it difficult to inflict punishment. }\end{array}$ \\
\hline laPin Şabartum & $\begin{array}{l}\text { It is a conditional clause that consists of the particle "Pin" preceded by the emphatic particle 'lām' and the } \\
\text { conditional tense. It conveys compassion for others. Therefore, it has the function for encouraging the } \\
\text { believers to forgive. }\end{array}$ \\
\hline La huwa khayrun lişs-şabrīn & It is a conditional main clause that indicates self-compassion. \\
\hline
\end{tabular}

For a scratch, the table above reveals that the Qur'an aims at creating a healthy personality for the world. This is achieved via encouraging the believers to have compassion for themselves and for others. In addition, these two values are buttressed by the principle of law with a view to ensuring fairness for all.

\subsubsection{Observance of Law}

The discourse of divine affection is used for motivating the believers to observe law. Observance of law is the first step towards forgiveness which is closely tied in with law. For a start, the Qur'an aims at bringing up peace in all communities by developing constructive frames. Therefore, it lays the foundations for a life in which peace prevails. It starts by encouraging people to forgive each other in a legal atmosphere that guarantees rights for everyone. It is a peaceful community in which a legal system applies for Muslims and non-Muslims alike. Therein lies the importance of the legal system that includes the legislative branch which is responsible for enacting laws and the executive branch that is responsible for enforcing laws. Therefore, the believer's life is a legalized culture in all walks of life. In response to an offense, the Qur'an encourages the offended to forgive if not, there is a legal path for him to take for the sake of justice. Allah (Exalted Be Him) says:

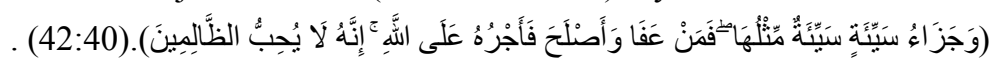

The recompense for an evil is an evil like thereof; but whoever forgives and makes reconciliation, his reward is with Allah. Verily, He likes not the zālimīna (oppressors, polytheists, and wrong doers. (ash-Shūra 42:40). 
According the verse, if there is any act of aggression, it shall be handled under the umbrella of law that guarantees rights for all. The verse reads: "And an injury shall receive a similar punishment". (ash-Shūra 42:40). The verse starts with angling the case from a legal frame using the forms " $j a z \bar{a}$ ?" i.e., punishment and "say?ah" i.e., an injury. Then, it concludes with a motivation for justice by the power of the divine love. The use of the nominal form " $j a z \bar{a}$ ?" angles the case legally. But, if the offended chooses to forgive, there is no need for any legal procedure. Otherwise, law must be enforced. So, the verse recommends forgiveness motivating the believers by the great reward of Allah. By and large, the whole case is motivated by affectional love that there is neither love nor hatred for the wrongdoers. Therefore, it would be better to forgive if not, the highest degree of justice should be achieved. Sometimes, it may be impossible to achieve such a one-to one way of punishment. The similarity is a means of promoting forgiveness by getting all parties to hold the letter of the law. It aims at keeping all parties healthy physically and psychologically. Divine love is a motivation for getting away from injustice by getting the offended away from aggression. Injustice is the same as revenge since they are a means to satisfy their desire for revenge. The stipulation of the same amount of punishment opens the door for forgiveness. A main objective of the verse is to save a life. However, it does not wish to turn the tables on the offended as in Shakespeare's play "The Merchant of Venice". In this play, Portia plans to get Shylock to hold to the letter of the law, and then to force him to apply it so strictly that it cannot be done: 'to take a pound of flesh without spilling any blood'. We are in a courtroom in which the defendant should enact law strictly no more or less.

\subsubsection{Fairness for All Parties}

In the preceding section, unfairness is not permitted at all. So, the Qur'an places emphasis on the similarity of punishment in many verses of which are the one below. It has been demonstrated that the Qur'an recommends forgiveness; otherwise, it instructs that legal procedures must be in force. Legal procedures must be in force for pushing forward the cycle of life and preventing the cycle of violence. The main objective of these measures is to keep order at all levels. The verse reads:

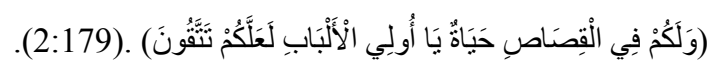

And there is (a saving of) life for you in Al-Qisās (the Law of Equality in punishment), O men of understanding, that you may become Al-Muttaqun (the pious - See V.2:2). (al-Baqarah 2:179).

This is the final stage to which people resort when forgiveness is not received. To reach this stage, there are many steps that should be undertaken ahead. Therefore, there is a close relation between legal procedures and forgiveness since forgiveness is the first step towards the enforcement of law. To achieve these goals, the Qur'an lays the foundations for constituting a legal system. It is a system that is divinely empowered for protecting the whole community by disciplinary measures.

\subsection{Deservingness}

Deservingness is one of the features which is justified by psychologists in a way that makes it fall under the righteous indignation frame. The Qur'an handles this feature in a different way. Deservingness is the result of entertaining the values of the hurt-perceived and the righteous indignation responses. The perception of deservingness occurs when the offended harbours the feeling of satisfaction when he sees the offender suffer. Psychologists tackles deservingness from a revengeful perspective. On answering the question, what satisfies the avenger? Gollwitzer et al. (2011, p. 365) state that it is sufficient to see the offender suffer for satisfying the desire of the offended for revenge. On seeing the offender suffers, the offended feels satisfied and perceives that everyone gets what he or she deserves. Therefore, it is deservingness that satisfies the avenger according to such psychological views. However, the Qur'an leaves no room for any revengeful desire by brining all parties to justice.

\subsubsection{Justice and Deservingness}

The Qur'anic treatment of revenge places emphasis on the legal principle to handle the desire of deservingness. If psychologists claim that revenge is universal, the sense of deservingness is overcome by achieving fairness in the Qur'an. The verse below instructs the offended to control and regulate his/her emotions reassuring him/her that there is an executive power for achieving justice. It is the ability to regulate one's emotions that counts. Thus, the three issues of justice, deservingness, and morality are handled by the principle of justice. The verse reads:

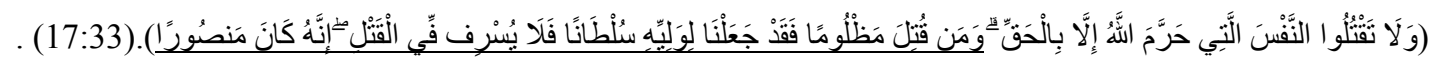

And do not kill anyone whose killing Allah has forbidden, except for a just cause. And whoever is killed wrongfully (Mazluman intentionally with hostility and oppression and not by mistake), We have given his heir the authority [to demand Qisas or to forgive, or to take Diyah (blood-money)]. But let him not exceed limits in 
the matter of taking life (i.e., he should not kill except the killer. Verily, he is helped (by the Islamic law). (al-Baqarah 17: 33).

The verse sets the basis for a legalized culture which is developed over the Qur'an by stressing the importance of justice. It is realized by the conditional sentence whoever is killed "unfairly" and the main clause "we have given his heir authority". These two issues of justice and legalization shuts the door on the value of deservingness. Indeed, the Qur'an does not encourage the adoption of the frame of deservingness because it wants to leave the door ajar fostering forgiveness all the time. For instance, God does hate unbelief; however, He does not hate unbelievers. A mental frame of this kind inspires believers with love rather than with hatred.

\subsection{Managing Aggressive Reactions}

The process of managing aggression starts in the mind. Analyzing the language of affection, we note that it never makes place for negative reaction. So, whenever there is a destructive value, the neutralized form of affection is used to get the believers away from such a ruinous mental frame. Affectional language develops constructive relationships with the other over time. There is no place for any destructive value such as aggression or treachery. How does the Qur'an control emotional reactions? To control this, it uses the strategy of neutralization of emotions. This objective is achieved by neutralizing emotions which takes the form of freezing reactions. It is settled that the way for revenge starts by harbouring any of the values of the hurt-perceived frame passing by the stage of revenge to aggressive reactions. Once a man responds to his rumination, he will develop a desire for revenge. In the two sections below, we tackle how the language of affection manages aggression and treachery. The two cases reveal the importance of the language of affection in facing the righteous indignation values.

\subsubsection{Managing Treachery}

Language of affection plays a major role in combating another aspect of the destructive mentality such as the feelings of the righteous indignation. To combat the desire for revenge, the Qur'an instructs the believers that they should not respond to their revengeful desires. Neutralization of one's emotions is an efficient means of getting rid of such negative mindsets. The process of neutralization is used for the inhibition of many negative energies such as treachery and aggression. By neutralization, I mean that whenever there is an offense, the injured party feels nothing towards the offender in a way that there is neither love nor hatred. Accordingly, neutralization is a means of the clearance of any evil suspicions. It paves the way for constructive behaviours. Regarding the existence of neutralization, Gasper et al. $(2019$, p. 1) state that there are three challenging views. The first view is the impossibility of feeling neutral. The second adopts a different view that affection must be divided into positive emotions or negative emotions. The third is that neutralization is not important because it does not affect cognition or behaviour. The present study holds the view of the existence of neutral affection which goes in line with the classification of the modes of reaction into fighting, fleeing, or freezing. The frozen mode stands for the neutralization of emotions. Such a view goes in line with the view of the Qur'an that emotions can be neutralized. The Qur'an creates a genuine rapport at all levels for emotional healing. The

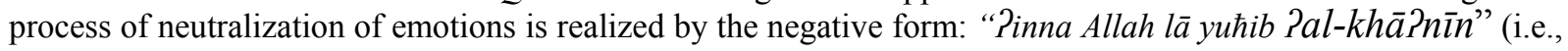
Indeed, God does not love the treacherous) as in the verse that reads:

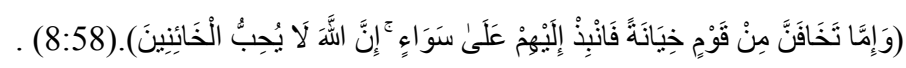

If you (O Muhammad) fear treachery from any people throw back (their covenant) to them (so as to be) on equal terms (that there will be no more covenant between you and them). Certainly, Allah likes not the treacherous. (al-Anfäl 8: 58).

The verse tells the Prophet (PBUH) that whenever he caught an enemy in breach of an agreement, he should tell them publicly that the agreement is null and void. Therefore, betrayal is prohibited because it is considered an act of deception. A divine language of affection is used to motivate the Prophet (PBUH) and the believers to not adopt this destructive mental frame. Thusly, the negative form 'Allah does not love' is a means of the inhibition of the righteous indignation values which lead to the relationship-destructive level. The motivational discourse of the divine language pushes forward the believers to adopt a more constructive frame. This type of divine motivations is used for the inhibition of harbouring any evil suspicions towards others. The question is 'why the verse combats such mental frames?'. The answer is that the first step towards rumination is harbouring negative feelings which, in turn, leads to revenge.

There are two linguistic anecdotes that call for analysis regarding the structure ' $l \bar{a} y u \hbar i b$ '. The first anecdote is the semantic feature of gradability which consists of the grammatical particle of negation 'là' (i.e., not in English) and the lexical item of love ' $y u \hbar i b$ ' (i.e., does not love). According to the gradable scale, the verse uses the lowest end of the scale of hatred that there are no feelings of hatred. This gradable feature supports our view of 
neutralization. Psychologically, it lays the foundations for a normal human interaction that should be adopted by humans. If someone offers us a good deed, he should be rewarded by the same and more. On the same basis, if there is an offense, there should not be any negative reaction which is realized by the case of 'al-lāhub' (neither love nor hatred). It uses the formulation "la $y u \hbar i b$ " to signify the meaning that there is neither love nor hatred for those who harbour any feelings of betrayal. The position of "do not love" is the lowest in the scale of emotions having a zero degree.

The language of affection, which is attributed to God and directed at participants, is of two main types: love and no love. When the participant is a human being, no hatred is directed at humans in the Qur'anic text because God creates man, and He loves him. Unlike the psychological view that denies the existence of neutralization, the Qur'an creates a three-ends scale of affection: love, no love, and hatred. The latter end of the scale of hatred is directed at actions, not humans. To motivate the believers, the language of love is used to revive their positive energies. In the same vein, to Keep them away from negative energies, the language of neutral affect is used.

If believers face an aggression, they should act positively. Whenever there is an offense or aggression, it is normal that there is a disposition to behave angrily. So, the verse uses the form of neutralization to overcome this disposition. A believer should never give a chance for ruminating evil suspicions. The second anecdote is that the use of "la $y u \hbar i b$ " invites 'love' into mind and it does not invite 'hatred'. If hatred is used instead, the verb "yakrah" (i.e., hate) does not invite 'love'. Therefore, the use of love has a rhetorical function of placing emphasis on love and indicating that 'revealed books' have nothing to do with hatred.

\subsubsection{Managing Aggression}

The clause 'Allah loves not the treacherous' in the verse (8:58) above shows the way of managing emotions by the Qur'an. It manages emotions positively in a way that gives no way for any sign of the righteous indignation values. Hence, the Qur'an nips in the bud the two frames above to prevent aggression. The prevention of aggression is motivated by the language of affection as in the verse that reads:

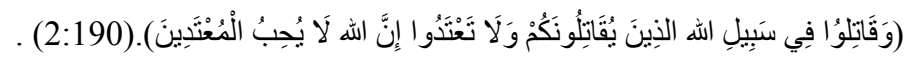

And fight in the Way of Allah those who fight you but transgress not the limits. Truly, Allah likes not the transgressors. This Verse is the first one that was revealed in connection with Jihad, but it was supplemented by another. (al-Baqarah 2:190).

The verse forbids aggression making use of affectional language that God does not love the aggressors. The formulation "la $y u \hbar i b$ " signifies the idea of neutralizing emotions by which there is neither love nor hatred for the aggressors. Emotively, it indicates that God hates their acts of aggression. Reviewing some selected forms of the discourse of affection, it goes without saying that the Qur'an plays a major role in handling destructive mental frames. It has a motivational power for switching a destructive mentality into a positive mentality.

\section{Conclusion}

On this basis, the study gets the reader familiar with the linguistic features of the hurt-perceived and the righteous indignation mindsets. In addition, it shows that rumination and inertia are the first step towards the development of such frames. It finds that the language of affection plays a motivational role in the inhibition of such destructive mindsets. It combats all forms of negative emotions such as the social and primary feelings of despair and sadness. Furthermore, it shows that the inhibition of the hurt-perceived values is the first step towards nipping in the bud the righteous indignation frame. This allows the conclusion that a link of causality features these two mindsets that the first leads to the second. Also, one of the main conclusions that can be drawn is that affectional language plays a major role in laying the foundations for a legalized culture with a view to achieving fairness for all. To achieve these goals, there are specific strategies which are used for transforming destructive mindsets into constructive ones. These include neuroplasticity, understanding, acceptance, responsibility, hope, faith, and trust in God. There is a close relationship between affectional language and the development of forgiveness, on one hand, and the inhibition of revenge, on the other hand. Above all else, there is a clear and close relation between the divine language of affection and the promotion of forgiveness. The first is used as a motivation for the second all over the data under analysis. Broadly speaking, our findings indicate that the authentic interpretation of the Qur'an helps in revealing the true values of the Qur'anic text. This type of understanding eradicates radicalism and ends all forms of violence that shake our societies today.

\section{References}

AI-Hilalī, M., \& Khān, M. (1414). Translation of the meanings of the Qur'an in the English Language. Madinah: King Fahd Complex for the Printing of the Holy Qur'an. 
al-Bukhāri. (2002). şaћeeћ al-Bukhāri. (1st ed.). Damascus and Beirut: Dār Ibn Kathīr.

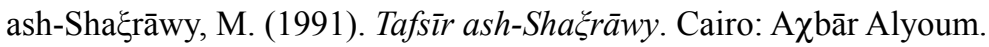

Elshout, M., Nelissen, R. M. A., van Beest, I., Elshout, S., \& van Dijk, W. W. (2019). Real-life Revenge May Not Effectively Deter Norm Violations. The Journal of Social Psychology, 160(3), 390-399. https://doi.org/10.1080/00224545.2019.1681351

Fleischman, R. P. (2004). Cultivating inner peace (2nd ed.). Seattle: Pariyatti Press. Is Revenge Justified? (n.d.). Retrieved January 12, 2020, from https://www.debate.org/opinions/is-revenge-justified

Gasper, K., Spencer, L. A., \& Hu, D. (2019). Does Neutral Affect Exist? How Challenging Three Beliefs About Neutral Affect Can Advance Affective Research. Front. Psychol., 10, 2476. https://doi.org/10.3389/fpsyg.2019.02476

Gollwitzer, M., \& Denzler, M. (2009). What Makes Revenge Satisfactory: Seeing the Offender Suffer or Delivering a Message. Journal of Experimental Social Psychology, 45(4), 840. https://doi.org/10.1016/j.jesp.2009.03.001

Gollwitzer, M., Meder, M., \& Schmitt, M. (2011). What gives victims satisfaction when they seek revenge? European Journal of Social Psychology, 41(3), 364-374. https://doi.org/10.1002/ejsp.782

Greenberg, M. (2016). The Stress-Proof Brain: Master Your Emotional Response to Stress Using Mindfulness \& Neuroplasticity. Oakland: New Harbinger Publications, Inc.

Ibn Kathīr. (1999). Tafsīr al-Qur'an al- ̧azīm (As-Sallāmah, M. Ed., 2nd ed., Vol. 2). Cairo: Dār tībah.

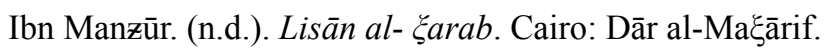

Knutson, B. (2004, August 27). Sweet Revenge? Science, 305(5688), 1246-1247. https://doi.org/10.1126/science.1102822

Koval, P., Kuppens, P., Allen, N. B., \& Sheeber, L. (2012). Getting Stuck in Depression: The Roles of Rumination and Emotional Inertia. Cognition \& Emotion, 26(8), 1412-1427. https://doi.org/10.1080/02699931.2012.667392

Löbner, S. (2002). Understanding Semantics (1st ed.). London and New York: Routledge Taylor \& Francis Group.

McCullough, M. (2000). Forgiveness as Human Strength: Theory, Measurement, and Links to Well-Being. Journal of Social and Clinical Psychology, 19(1), 43-55. https://doi.org/10.1521/jscp.2000.19.1.43

Nolen-Hoeksema, S., Wisco, B., \& Lyubomirsky, S. (2008). Rethinking Rumination. Perspectives on Psychological Science, 3(5), 400-424. https://doi.org/10.1111/j.1745-6924.2008.00088.x

Potter-Efron, R. (2012). Healing the Angry Brain: Understanding the Way Your Brain Works Can Help You Control Anger and Aggression. Canada: New Harbinger Publications, Inc. https://doi.org/10.1037/e506242013-121

Scheiter, K. M. (2016). Introduction to Ethics of Forgiveness and Revenge. Philosophia, 44, 313-315. https://doi.org/10.1007/s11406-016-9720-0

Warrel, M. (2012, Sep. 19). The Glass Half Full or Empty? Why Optimists Are Happier, Healthier \& Wealthier! Forbes. com. Retrieved from https://www.forbes.com/sites/margiewarrell/2012/09/19/see-the-glass-half-empty-or-full-7-keys-for-optimis m-in-tough-times/\#28102bc767f8

\section{Notes}

Note 1. Indeed, the language of affection in the Qur'an aims at getting the believers rid of all negative energies such as depression. Depression opens the door for psychological and physical diseases. Herein lies the importance of a contextual analyses of the discourse of Uhud that starts with drawing their attention to the potential result of the adoption of the hurt perceived. Then, it uses the form of neutralization that mediates between the result and the neurological programming process. It plays a pivotal role in way that leads to recovery. 


\section{Copyrights}

Copyright for this article is retained by the author, with first publication rights granted to the journal.

This is an open-access article distributed under the terms and conditions of the Creative Commons Attribution license (http://creativecommons.org/licenses/by/4.0/). 